\title{
Investigation of Reasons of Social Media Usage of Physical Education and Sports School Students
}

\author{
Mehmet Yıldırım ${ }^{1} \&$ Sema Uslu ${ }^{1}$ \\ ${ }^{1}$ Yozgat Bozok University, Yozgat, Turkey \\ Correspondence: Mehmet Yıldırım, Yozgat Bozok University, School of Physical Education and Sports, Yozgat, \\ Turkey. E-mail: mehmet2682@hotmail.com
}

Received: November 12, 2018

Accepted: December 14, 2018

Online Published: December 19, 2018

doi:10.5430/ijhe.v7n6p129

URL: https://doi.org/10.5430/ijhe.v7n6p129

\begin{abstract}
The aim of this research is to determine the reasons of social media usage of students studying in school of physical education and sport. The universe of the research was created 750 students from Yozgat Bozok University School of Physical Education and Sports. The sample of the study consisted of 283 students who were studying at different departments of Physical Education and Sport Department of Yozgat Bozok University in 2018-2019 academic year. Survey method was used in the study. Information on the demographic characteristics of the students was obtained by 'personal information form. Information about determining the reasons of social media usage for students, Cemrek et al. (2014) developed by the usage of social media scale was obtained. The data were transferred to SPSS 18 software program for statistical operations. Frequency analysis, percentage analysis, arithmetic mean, $\mathrm{t}$ test, Anova analysis and post hoc tests were used to analyze the data.

As a result of the analyzes performed; Statistically significant differences were found among the reasons of social media usage according to the education department, the purpose of using the internet, the most followed social media tool and the time variables spent on social media during the day $(\mathrm{p}<.05)$. There were no statistically significant differences according to gender variable ( $p>05)$.
\end{abstract}

Keywords: sports, social media, University, student

\section{Introduction}

The most remarkable invention of the $20^{\text {th }}$ century is undoubtedly Internet, which was put into service in the late 1980s. With the advent of the computer technology and subsequent technological developments, a brand new phenomenon and process was born, which was called "Information Age" (Aziz, 2008). The Internet both shaped and was shaped by the society in a number of different ways. While most people today consider the Internet as a medium of interpersonal chatting and surfing, they do not often realize that it is also a tool of communication, correspondence, information and learning (Dikener, 2010). However, many developing countries approach the Internet not only as a medium of entertainment but also a means of development (Solmaz et al. 2013).

The Internet diverges from other forms of conventional media. "Web applications on the Internet provide a simultaneous and bidirectional information flow between the communicating parties (Sayımer, 2008). Thanks to its constantly developing content, the Internet experiences now its golden age, which touches upon many people's lives. In today's world, countless people benefit from social media in many ways such as communicating with their friends, checking out their friends' photos and posts, sending and receiving messages, doing free time activities, obtaining information, playing games and following current news (Solmaz et al. 2013).

Social media is a medium for mutual communication in which people share their information, ideas and interests (Aydoğan and Akyüz, 2010). It can be generally defined as individuals' participation in an online discussion on a certain topic (Fouts, 2009). "Thanks to social media, an unprecedentedly giant and easy sharing platform around the world has entered into our lives (Kahraman, 2010). Another definition states that social media is the sum of highly scalable and accessible information technologies and techniques which enable an individual to easily influence other groups of individuals (Blossom, 2009).

Social media is a vast field which rapidly integrated the world of Internet into our lives (Weinberg, 2009). Although it is called "media", it possess many features that quite differ from conventional forms of media. Its most distinct and original difference is an individual's opportunity to create content, comment on this content and contribute to it (Scott, 2010). 
The rapidly growing popularity and accessibility of social media has particularly attracted attention in the last ten years (Donelan, 2016). Social network sites pave the way for a suitable environment in which individuals can share their personal information via communication networks (Jang et al. 2016). These sites have evolved into an indispensable meeting point because it publishes information about millions of people (Viejo and Sanchez, 2016). "People tend to use the Internet and web applications more often owing to the rapid technological developments. With the proliferation of mobile applications, technology has become a solid part of our lives and is now accessible at any moment." (Aslanyürek et al. 2015). Communication and information technologies have turned into occupations and shops, thus influencing the way in which people obtain and share information and cooperate and communicate with each other (Donelan, 2016).

Giving people the opportunity to broadcast their private lives to the world, social media now dominates the means of communication as a result of a technological revolution and social communication networks all over the world (Baughman, 2010). Being one of the mostly used means of communication nowadays, social network sites enable people to share their personal profiles with other people around the world (Haciefendioğlu, 2010). They opened the way for a new communication network in which people can interact with each other through photos, videos and audio files without any spatial or temporal limitation (Ortar and Argın, 2014). Facebook, Twitter, Instagram, Vine, Youtube and Swarm can be listed as the most popular communication networks in today's world (Kural et al. 2016).

Introduced in Turkey in 1994, the Internet became widespread during the early 2000s. However, the use of social media in Turkey and around the world has not even reached 10 years. The popularization of smart phones in recent years has resulted in the active contribution of social media to world agenda, making it one of the most indispensable means of communication in the $21^{\text {st }}$ century (Ebizmba, 2015). Thus, social media now occupies such a critical position that it deeply influences societies and business world, and is continuing to direct wider masses day by day (Küçükali, 2016).

Nearly 75 percent of the young population in Turkey uses the Internet, and spends a certain amount of their time on social media sites as active users having accounts on one or more social media sites (Küçükali, 2016). Within the framework of this fact, the present study mainly aims to identify the impact of constantly growing social media sites on students studying at different departments of School of Physical Education and Sports and these students' purposes of social media use.

In this respect, the following research question was analyzed:

Are there any statistically significant differences between purposes of for social media use among students studying at School of Physical education and Sports in terms of the following variables?
- Gender
- Department
- Purpose of social media use
- Mostly used social media site
- Amount of time spent on social media? $(\mathrm{p}<0.05)$.

\section{Method}

In this section, the population and sample of the study, data collection tools and statistical methods for data analysis are described.

\subsection{Study Group}

The population of the study consists of 800 students studying at different departments of School of Physical education and Sports at Yozgat Bozok University during 2018-2019 academic year. The sample of the study consists of 283 students studying at different departments of School of Physical education and Sports at Yozgat Bozok University during 2018-2019 academic year and selected using purposeful sampling method.

\subsection{Collection of Data}

Because of its cost-effectiveness, feasibility and suitability for data collection from dispersed and large masses in a short period, questionnaire, which is one of the primary source research tools, was used as a data collection tool in the present study. The questionnaire form consists of two parts. The first part identifies participants' personal and social features by using limited items, while the second part uses a 5-point Likert type scale to identify participants' purposes of social media use. 


\subsection{Purposes of Social Media Use Scale}

A scale developed by Cemrek et al. (2014) was used in the present study to identify students' purposes of social media use. It is a 26 -item scale with five sub-dimensions and responses ranging from "1 (strongly disagree) to 5 (strongly agree)". The sub-dimensions of the scale are named as entertainment, social interaction, awareness, self-expression and contribution to social change.

In the present study, the reliability coefficient of the scale was calculated as .93 . The reliability coefficients of the sub-dimensions are as follows: .77 for entertainment, .78 for social interaction, .77 for awareness, .82 for self-expression and .84 for contribution to social change. A reliability coefficient between .70 and .90 is accepted as highly reliable in the literature (Bagozzi and Yi, 1988; 76-94, Nunnally and Bernstein, 1994). Therefore, it can be stated that the scale meets the requirements for an acceptable internal consistency reliability coefficient.

\subsection{Analysis of Data}

The data obtained in the present study was analyzed using SPSS 18.0 package program. Prior to the statistical data analysis, the data should be prepared for statistical analysis, and skewness and kurtosis coefficients should be particularly calculated well (Şimşek, 2007; 74). A skewness coefficient of (+-2) and a kurtosis coefficient of (+-7) indicates a normal data distribution (West et al., 1995; Şencan, 2005; 376, Şimşek, 2007; 74). In the present study, skewness and kurtosis coefficients were calculated as $0.015 /-0.556$ and $0.132 /-0.709$, respectively. These results indicate that the data display a normal distribution, and parametric tests were used in the statistical analysis.

For the data analysis, frequency analysis was used to describe students' demographic features. Additionally, $t$ test and ANOVA test were used to identify differences among purposes of social media in terms of demographic variables, and, finally, multiple comparison (Post-Hoc LSD and Tamhane 2) tests were used depending on the variance homogeneity. The level of statistical significance was taken as 0.05 .

\section{Results}

The findings related to participants' demographic features are given in Table 1.

Table 1. Students' Demographic Features

\begin{tabular}{|c|c|c|c|}
\hline & & $\mathrm{N}$ & $\%$ \\
\hline \multirow{2}{*}{ Gender } & Female & 125 & 44.2 \\
\hline & Male & 158 & 55.8 \\
\hline \multirow{3}{*}{ Department } & Physical Education and Sports Teaching & 88 & 31.1 \\
\hline & Coaching Education & 89 & 31.4 \\
\hline & Sports Management & 106 & 37.5 \\
\hline \multirow{9}{*}{ Purpose of Internet Used } & E-mails & 6 & 2.1 \\
\hline & Social Media & 201 & 71.0 \\
\hline & Reading newspaper & 4 & 1.4 \\
\hline & Watching TV shows & 4 & 1.4 \\
\hline & Listening to Music & 18 & 6.3 \\
\hline & Shopping & 5 & 1.7 \\
\hline & For research on interesting topics & 35 & 12.3 \\
\hline & Playing games & 6 & 2.1 \\
\hline & Downloading programs & 4 & 1.4 \\
\hline \multirow{5}{*}{ Mostly Used Social Media Site } & Facebook & 4 & 1.4 \\
\hline & Twitter & 10 & 3.5 \\
\hline & Instagram & 215 & 76.0 \\
\hline & Youtube & 40 & 14.1 \\
\hline & Whatsapp & 14 & 4.9 \\
\hline \multirow{4}{*}{ Daily Time Spent on Social Media } & Less than 1 hour & 34 & 12.0 \\
\hline & $1-3$ hours & 106 & 37.4 \\
\hline & 3-5 hours & 76 & 26.8 \\
\hline & 5 hours and more & 67 & 23.6 \\
\hline
\end{tabular}


According to Table 1, 158 students (55.8\%) are males while 125 of them $(44.2 \%)$ are females. 88 students (31.1\%) study physical education and sports teaching, 89 students (31.4\%) study coaching education, and 106 students $(37.5 \%)$ study sports management. A large portion of students $(71.0 \%)$ uses the Internet for social media sites. The mostly used social media site among students is Instagram (76.0\%). 34 students (12.0\%) spend less than 1 hour on social media, while 106 of them (37.4\%) spend 1-3 hours, 76 of them $(26.8 \%)$ spend $3-5$ hours, and 67 of them (23.6\%) spend 5 hours and more.

$\mathrm{t}$ test findings related to the comparison of mean sub-dimension scores in terms of gender are given in Table 2.

Table 2. $\mathrm{t}$ test findings related to the comparison of mean sub-dimension scores in terms of gender

\begin{tabular}{|c|c|c|c|c|c|c|}
\hline & Gender & $\mathrm{N}$ & Mean Score & $\mathrm{sd}$ & $\mathrm{t}$ & $\mathrm{p}$ \\
\hline \multirow[t]{2}{*}{ Entertainment } & Female & 125 & 3.42 & 0.77 & \multirow[t]{2}{*}{-.500} & \multirow[t]{2}{*}{.617} \\
\hline & Male & 158 & 3.47 & 0.81 & & \\
\hline \multirow[t]{2}{*}{ Social Interaction } & Female & 125 & 3.19 & 0.85 & \multirow[t]{2}{*}{-.255} & \multirow[t]{2}{*}{.799} \\
\hline & Male & 158 & 3.21 & 0.79 & & \\
\hline \multirow[t]{2}{*}{ Awareness } & Female & 125 & 3.58 & 0.99 & \multirow[t]{2}{*}{.313} & \multirow[t]{2}{*}{.755} \\
\hline & Male & 158 & 3.54 & 0.92 & & \\
\hline \multirow[t]{2}{*}{ Self-expression } & Female & 125 & 3.17 & 1.05 & \multirow[t]{2}{*}{.320} & \multirow[t]{2}{*}{.749} \\
\hline & Male & 158 & 3.12 & 1.14 & & \\
\hline \multirow[t]{2}{*}{ Contribution to Social Change } & Female & 125 & 3.22 & 1.14 & \multirow[t]{2}{*}{.175} & \multirow[t]{2}{*}{.861} \\
\hline & Male & 158 & 3.20 & 1.15 & & \\
\hline
\end{tabular}

It can be seen in Table 2 that no statistically significant differences were found among mean sub-dimension scores in terms of gender $(\mathrm{p}>.05)$.

ANOVA findings related to the comparison of mean sub-dimension scores in terms of department are given in Table 3 . 
Table 3. ANOVA findings related to the comparison of mean sub-dimension scores in terms of department

\begin{tabular}{|c|c|c|c|c|c|c|c|c|c|c|c|}
\hline & Group & $\mathrm{N}$ & $\bar{x}$ & S.s & $\begin{array}{l}\text { S.of } \\
\text { Var. }\end{array}$ & $\begin{array}{l}\text { Sum } \\
\text { Sq. }\end{array}$ & $\mathrm{df}$ & $\begin{array}{l}\text { M. } \\
\text { Sq. }\end{array}$ & $\mathrm{F}$ & $\mathrm{p}$ & $\begin{array}{l}\text { Significant } \\
\text { Difference }\end{array}$ \\
\hline \multirow[t]{3}{*}{ Entertainment } & $\begin{array}{l}\text { Physical } \\
\text { Ed. Sports } \\
\text { Teaching }\end{array}$ & 88 & 3.53 & .74 & $\begin{array}{l}\text { Between } \\
\text { Groups }\end{array}$ & 1.58 & 2 & 0.79 & \multirow{3}{*}{1.253} & \multirow{3}{*}{.287} & \multirow{3}{*}{ - } \\
\hline & $\begin{array}{l}\text { Coaching } \\
\text { Education }\end{array}$ & 89 & 3.35 & .91 & $\begin{array}{l}\text { Within } \\
\text { Groups }\end{array}$ & 176.87 & 280 & $\overline{0.63}$ & & & \\
\hline & $\begin{array}{l}\text { Sports } \\
\text { Man. }\end{array}$ & 106 & 3.47 & .72 & Total & 178.45 & 282 & & & & \\
\hline \multirow[t]{4}{*}{$\begin{array}{l}\text { Social } \\
\text { Interaction }\end{array}$} & $\begin{array}{l}\text { Physical } \\
\text { Ed. Sports } \\
\text { Teaching }\end{array}$ & 88 & 3.37 & .85 & $\begin{array}{l}\text { Between } \\
\text { Groups }\end{array}$ & 4.26 & 2 & 2.13 & \multirow{4}{*}{3.248} & \multirow{4}{*}{$.040^{*}$} & \multirow[t]{4}{*}{$\begin{array}{c}\text { Teaching/ } \\
\text { Coaching, } \\
\text { Management }\end{array}$} \\
\hline & $\begin{array}{l}\text { Coaching } \\
\text { Education }\end{array}$ & 89 & 3.06 & .80 & $\begin{array}{l}\text { Within } \\
\text { Groups }\end{array}$ & 183.83 & 280 & .65 & & & \\
\hline & Sports & 106 & 3.18 & .77 & Total & 188.10 & 282 & & & & \\
\hline & Man. & & & & & & & & & & \\
\hline \multirow[t]{3}{*}{ Awareness } & $\begin{array}{l}\text { Physical } \\
\text { Ed. Sports } \\
\text { Teaching }\end{array}$ & 88 & 3.64 & .91 & $\begin{array}{l}\text { Between } \\
\text { Groups }\end{array}$ & 4.51 & 2 & 2.25 & \multirow{3}{*}{2.517} & \multirow{3}{*}{.083} & \multirow{3}{*}{ - } \\
\hline & $\begin{array}{l}\text { Coaching } \\
\text { Education }\end{array}$ & 89 & 3.37 & .98 & $\begin{array}{l}\text { Within } \\
\text { Groups }\end{array}$ & 251.08 & 280 & .89 & & & \\
\hline & $\begin{array}{l}\text { Sports } \\
\text { Man. }\end{array}$ & 106 & 3.64 & .94 & Total & 255.60 & 282 & & & & \\
\hline \multirow[t]{3}{*}{ Self-expression } & $\begin{array}{l}\text { Physical } \\
\text { Ed. Sports } \\
\text { Teaching }\end{array}$ & 88 & 3.30 & 1.08 & $\begin{array}{l}\text { Between } \\
\text { Groups }\end{array}$ & 4.55 & 2 & 2.27 & \multirow{3}{*}{1.894} & \multirow{3}{*}{.152} & \multirow{3}{*}{ - } \\
\hline & $\begin{array}{l}\text { Coaching } \\
\text { Education }\end{array}$ & 89 & 2.98 & 1.10 & $\begin{array}{l}\text { Within } \\
\text { Groups }\end{array}$ & 336.83 & 280 & 1.20 & & & \\
\hline & $\begin{array}{l}\text { Sports } \\
\text { Man. }\end{array}$ & 106 & 3.14 & 1.10 & Total & 341.39 & 282 & & & & \\
\hline \multirow{3}{*}{$\begin{array}{l}\text { Contribution } \\
\text { to Social } \\
\text { Change }\end{array}$} & $\begin{array}{l}\text { Physical } \\
\text { Ed. Sports } \\
\text { Teaching }\end{array}$ & 88 & 3.34 & 1.03 & $\begin{array}{l}\text { Between } \\
\text { Groups }\end{array}$ & 5.58 & 2 & 2.79 & \multirow{3}{*}{2.128} & \multirow{3}{*}{.121} & \multirow{3}{*}{ - } \\
\hline & $\begin{array}{l}\text { Coaching } \\
\text { Education }\end{array}$ & 89 & 3.01 & 1.28 & $\begin{array}{l}\text { Within } \\
\text { Groups }\end{array}$ & 367.66 & 280 & $\overline{1.31}$ & & & \\
\hline & $\begin{array}{l}\text { Sports } \\
\text { Man. }\end{array}$ & 106 & 3.27 & 1.10 & Total & 373.24 & 282 & & & & \\
\hline
\end{tabular}

It can be understood from Table 3 that a statistically significant difference was observed among mean social interaction sub-dimension scores in terms of department $(F=3.248 ; p=0.04)$. It was found out that students studying physical education and sports teaching had a higher level of social interaction compared to those studying coaching education and sports management.

ANOVA findings related to the comparison of mean sub-dimension scores in terms of purposes of Internet use are given in Table 4. 
Table 4. ANOVA findings related to the comparison of mean sub-dimension scores in terms of purposes of Internet use

\begin{tabular}{|c|c|c|c|c|c|c|c|}
\hline & S. of Var. & S. of Sq. & $\mathrm{df}$ & M. Sq. & $\mathrm{F}$ & $\mathrm{p}$ & $\begin{array}{l}\text { Significant } \\
\text { Difference }\end{array}$ \\
\hline \multirow[t]{3}{*}{ Entertainment } & Between groups & 10.03 & 8 & 1.25 & 2.041 & $.042^{*}$ & For social media / \\
\hline & Within groups & 168.41 & 274 & .61 & & & For Research \\
\hline & Total & 178.45 & 282 & & & & \\
\hline \multirow[t]{3}{*}{ Social Interaction } & Between groups & 4.87 & 8 & .60 & 911 & .508 & \\
\hline & Within groups & 183.22 & 274 & .66 & & & - \\
\hline & Total & 188.10 & 282 & & & & \\
\hline \multirow[t]{3}{*}{ Awareness } & Between groups & 9.20 & 8 & 1.15 & 1.280 & .254 & \\
\hline & Within groups & 246.39 & 274 & .89 & & & - \\
\hline & Total & 255.60 & 282 & & & & \\
\hline \multirow[t]{3}{*}{ Self-expression } & Between groups & 5.26 & 8 & .65 & .536 & .829 & \\
\hline & Within groups & 336.12 & 274 & 1.22 & & & - \\
\hline & Total & 341.39 & 282 & & & & \\
\hline \multirow{3}{*}{$\begin{array}{l}\text { Contribution to } \\
\text { Social Change }\end{array}$} & Between groups & 10.36 & 8 & 1.29 & .979 & .453 & \\
\hline & Within groups & 362.87 & 274 & 1.32 & & & - \\
\hline & Total & 373.24 & 282 & & & & \\
\hline
\end{tabular}

${ }^{*} \mathrm{p}<.05,{ }^{* * *} \mathrm{p}<.01$

It is evident from Table 4 that a statistically significant difference was revealed among mean entertainment sub-dimension scores in terms of purposes of Internet use $(F=2.041 ; p=.042)$. Students who used the Internet for social media enjoyed more entertainment compared to those who used the Internet for research.

ANOVA findings related to the comparison of mean sub-dimension scores in terms of the mostly used social media site are given in Table 5.

Table 5. ANOVA findings related to the comparison of mean sub-dimension scores in terms of the mostly used social media site

\begin{tabular}{|c|c|c|c|c|c|c|c|}
\hline & S. of Var. & S.of Sq. & df & M.Sq. & $\mathrm{F}$ & $\mathrm{p}$ & Significant Difference \\
\hline \multirow[t]{4}{*}{ Entertainment } & Between groups & 7.94 & 4 & 1.98 & 3.237 & $.013^{*}$ & Facebook / Twitter \\
\hline & Within groups & 170.51 & 278 & .61 & & & Instagram \\
\hline & Total & 178.45 & 282 & & & & Youtube \\
\hline & & & & & & & Whatsapp \\
\hline \multirow[t]{3}{*}{ Social Interaction } & Between groups & 7.34 & 4 & 1.83 & 2.825 & $.025^{*}$ & Instagram \\
\hline & Within groups & 180.75 & 278 & .65 & & & / Youtube \\
\hline & Total & 188.10 & 282 & & & & \\
\hline \multirow[t]{3}{*}{ Awareness } & Between groups & 3.88 & 4 & .97 & 1.072 & .371 & - \\
\hline & Within groups & 251.72 & 278 & .90 & & & \\
\hline & Total & 255.60 & 282 & & & & \\
\hline \multirow[t]{3}{*}{ Self-expression } & Between groups & 8.19 & 4 & 2.04 & 1.709 & .148 & - \\
\hline & Within groups & 333.19 & 278 & 1.19 & & & \\
\hline & Total & 341.39 & 282 & & & & \\
\hline \multirow{3}{*}{$\begin{array}{l}\text { Contribution to } \\
\text { Social Change }\end{array}$} & Between groups & 19.47 & 4 & 4.86 & 3.825 & $.005^{*}$ & Whatsapp \\
\hline & Within groups & 353.77 & 278 & 1.27 & & & / Facebook, Twitter, Youtube \\
\hline & Total & 373.24 & 282 & & & & \\
\hline
\end{tabular}

${ }^{*} \mathrm{p}<.05,{ }^{* * *} \mathrm{p}<.01$

It can be observed in Table 5 that statistically significant differences were found among mean entertainment, social interaction and contribution to social change sub-dimension scores $(\mathrm{p}<.05)$. In the entertainment sub-dimension, 
Twitter, Instagram, Youtube and Whatsapp users enjoyed more entertainment in social media sites compared to Facebook users. In the social interaction sub-dimension, Instagram users had a higher level of social interaction compared to Youtube users. Finally, Whatsapp users' contribution to social change was higher compared to Facebook, Twitter and Youtube users.

ANOVA findings related to the comparison of mean sub-dimension scores in terms of daily time spent on social media sites are given in Table 6 .

Table 6. ANOVA findings related to the comparison of mean sub-dimension scores in terms of daily time spent on social media sites

\begin{tabular}{|c|c|c|c|c|c|c|c|}
\hline & S. of Var. & S. of Sq. & $\mathrm{df}$ & M. Sq. & $\mathrm{F}$ & $\mathrm{p}$ & Significant Difference \\
\hline \multirow[t]{4}{*}{ Entertainment } & Between groups & 6.49 & 3 & 2.16 & \multirow[t]{4}{*}{3.515} & \multirow[t]{4}{*}{$.016^{*}$} & Less than 1 hour \\
\hline & Within groups & 171.95 & 279 & .61 & & & / 1-3 hours, \\
\hline & Total & 178.45 & 282 & & & & 3-5 hours, \\
\hline & & & & & & & 5 hours and more \\
\hline \multirow[t]{3}{*}{ Social Interaction } & Between groups & 2.93 & 3 & .97 & \multirow[t]{3}{*}{1.475} & \multirow[t]{3}{*}{.222} & \multirow[t]{3}{*}{-} \\
\hline & Within groups & 185.16 & 279 & .66 & & & \\
\hline & Total & 188.10 & 282 & & & & \\
\hline \multirow[t]{3}{*}{ Awareness } & Between groups & 2.11 & 3 & .70 & \multirow[t]{3}{*}{0.775} & \multirow[t]{3}{*}{.509} & \multirow[t]{3}{*}{-} \\
\hline & Within groups & 253.49 & 279 & .90 & & & \\
\hline & Total & 255.60 & 282 & & & & \\
\hline \multirow[t]{3}{*}{ Self-expression } & Between groups & 1.87 & 3 & .62 & \multirow[t]{3}{*}{0.514} & \multirow[t]{3}{*}{.672} & \multirow[t]{3}{*}{-} \\
\hline & Within groups & 339.51 & 279 & 1.21 & & & \\
\hline & Total & 341.39 & 282 & & & & \\
\hline \multirow{3}{*}{$\begin{array}{l}\text { Contribution to } \\
\text { Social Change }\end{array}$} & Between groups & 6.52 & 3 & 2.17 & \multirow[t]{3}{*}{1.654} & \multirow[t]{3}{*}{.177} & \multirow[t]{3}{*}{-} \\
\hline & Within groups & 366.72 & 279 & 1.31 & & & \\
\hline & Total & 373.24 & 282 & & & & \\
\hline
\end{tabular}

Table 6 indicates that there was a statistically significant difference among mean entertainment sub-dimension scores in terms of daily time spent on social media $(\mathrm{F}=3.515 ; \mathrm{p}=.016)$. It was found out that students who spent less than 1 hour on social media sites enjoyed less.

\section{Discussion}

In today's world, social media sites have become an integral part of our lives, which is also clearly demonstrated by the present study. It can be generally stated that more than half of the participants actively use social media sites. Similarly, most of the participants log in their social media accounts every day, and spend at least one hour in these sites. This can be also understood from the fact that participants use social media as a tool for different purposes such as entertainment, social interaction, following daily news, self-expression and contribution to social change. In other words, many of our daily activities are intertwined with the Internet and social media.

The present study aimed to identify the impact of social media on students studying at different departments of Physical Education and Sports and their purposes of social media use. In this respect, 283 students studying at different departments of School of Physical education and Sports at Yozgat Bozok University during 2018-2019 academic year and selected using purposeful sampling method comprised the sample of the study.

While 125 (44.2\%) female students participated in the study, the number of participating male students was 158 $(55.8 \%)$. As for the departments, 88 students $(31.1 \%)$ study physical education and sports teaching, 89 students (31.4\%) study coaching education and 106 students (37.5\%) study sports management.

The findings related to purposes of Internet use demonstrate that an overwhelming part of participants (71.0\%), 201 students, use the Internet "for social media", which corresponds to nearly two-third of all participants. This can be associated with the increasing number of applications (social media networks) within social media platforms and a 
resulting popularity among individuals. Two studies by Kural et al. (2016) (\%96.7) and Solmaz et al. (2013) (\%97.6) and Önür, Kalaman and Çoban (2015) (\%96.0) reported that nearly all of the participants used the Internet as a tool of social media, which overlaps the present study despite a lower percentage. When these findings are taken into consideration, it can be concluded that social media sites still occupy a central position.

It was found out in the present study that the mostly used social media site is Instagram with 215 users (76.0\%), followed by Youtube with 40 users (\%14.1), Whatsapp with 14 users (\%4.9), Twitter with 10 users (3.5\%) and Facebook with 4 users $(1.4 \%)$. Therefore, it is clear that an important part of the participants actively use Instagram. It can be argued that the development of social media networks along with advancing technology is a major contributor to the popularity of this social media site. Because people use Instagram for different activities such as chatting their friends, live broadcast, news, following world agenda, watching videos and listening to music in a single application (social media network), it is not surprising that people often prefer this application and become satisfied with the service, thus recommending other people to use it. As a result, it was revealed in the present study that Instagram was the most popular social media network. Similar to the present study, in a study by Kural et al. (2016), it was demonstrated that the mostly used social media site was Instagram with $89.3 \%$. On the other hand, another study by Abanoz (2018) reported that Facebook (31.5\%) was the most popular social media site among the participants, while Instagram was the least popular (5.4\%), which remarkably differs from the present study. Similarly, Kilci (2018) indicated that Facebook (46.3\%) had a higher level of popularity among participants, which also differs from the findings of the present study.

As for participants' daily time spent on social media, 1-3 hours represented the most popular answer with 37.4\% (106). Therefore, it is evident that participants spend at least 1 hour on social media sites every day, and that there is not a single person who does not log in a social media account during the day. Vural and Bat (2010) reported that $53.6 \%$ of the participants spent 1-3 hours on social media during the day, which overlaps the findings of the present study. Similarly, a study by Abanoz (2018) also demonstrated that $45.9 \%$ of the participants spent at least 2-3 hours on social media sites. However, according to Kilci (2018), daily time spent on social media sites is more than 3 hours, which is a different finding compared to the present study.

The statistical analysis in the present study indicated no statistically significant differences among students' purposes of social media use in terms of gender ( $p>0.05$ ). Thus, it can be inferred that both genders actively use social media sites and that their purposes of use display similarities. Toruk (2018), Ilgar and Cihan (2018), too, reached findings similar to the present study. On the other hand, unlike the present study, Karakoç and Taydaş reported that (2013) female users (36.5\%) had a slightly longer duration of active social media use by 2-3 hours compared to male users (32.8\%). In a similar vein, it was found out in a study by Kural et al. (2016) that male participants used social media more actively and tended to be closer to socialization via social media compared to female participants. This finding, too, contradicts the findings of the present study.

It was observed in the present study that students studying physical education and sports teaching had a higher level of using social media for social interaction compared to those studying coaching education and sports management. Therefore, it can be said that students studying physical education and sports use social media more actively compared to students studying coaching education and sports management to avoid feeling of loneliness, feel belonging to a certain group, express themselves better in the social media, become aware of what happens around them and follow current developments.

The findings demonstrated that students who used the Internet as a tool of social media found it more enjoyable compared to students who used the Internet for research. This is because all individuals are attracted to developments and innovations in the social media due to technological advancements in today's world, which encourages them to use these social networks. The widespread use and popularity of social media in a social circle, the idea of meeting new people, an effort to relieve from daily stress and an environment to spend free time in an enjoyable way will attract individuals to social media sites, thus making its use more interesting than research. Solmaz et al. (2013), too, report results similar to those of the present study.

In terms of the mostly used social media site, the present study indicates that Twitter, Instagram, Youtube and Whatsapp users find social media more enjoyable compared to Facebook users, and that Instagram users tend to use social media for social interaction, while Whatsapp users use this application for contribution to social change. Because Twitter, Instagram, Youtube and Whatsapp are updated and changed day by day, Facebook is not preferred anymore by the majority of the users. It can be also argued that individuals can access all different contents in a single application instead of following different social media sites for different purposes such as listening to music, 
watching videos, chatting with friends, meeting new people and following current news, which makes these sites enjoyable and attractive for these individuals.

It was also observed in the present study that students who used social media for entertainment started to spend a longer time on social media. Individuals are usually attracted by popular things and tend to use them to spend their time in a more enjoyable way. As they chat with other people and communicate with new people, they are more likely to feel themselves important. As a result, a person who feels him/herself important will probably spend more hours on social media sites without realizing.

\section{Conclusion}

In conclusion, the present study makes it clear that the use of Internet and social media sites have become an active and popular way of communication, sharing and socialization in a rapidly globalizing and transforming world. It is of vital importance to more effectively use these communication, sharing and socialization networks which occupy a critical position in our daily lives. The following recommendations can be made for a better and more efficient use of the Internet and social media sites:

- Children, adults and parents should attend education seminars on the Internet and social media.

- Leaflets, public service advertisements and posters should be prepared to give information about the use of Internet and social media.

- Children and teenagers should experience real life situations in order to realize that life is not limited to only the Internet and social media sites.

- Children and teenagers should not be banned from using the Internet and social life, and new solutions should be offered for them.

- Children and teenagers should be urged to communicate face-to-face with their friends since their use of daily language is exposed to degeneration and verbal skills lack harmony.

\section{References}

Abanoz, E.I. (2018). The impact of private gym members' interest in sports and perceived value on their use of social media, PhD Thesis, University of Sakarya, Institute of Educational Sciences, Sakarya.

Aslanyürek, M., Gürdal, S., Dursun, S., Tunçel, E., Ayan, M. (2015). The reality of social media and assessment of vocational higher education school students' perception of social media), Electronic Journal of Vocational Colleges, 5(6), 1-9.

Aydoğan, F., Akyüz, A. (2010). The Internet in the Second Media Age. İstanbul: Alfa Publications.

Aziz, A. (2008). Introduction to Communication. İstanbul: Aksu Bookstore.

Bagozzi, R.P., Yi, Y. (1988). On the evaluation of structural equation models, Academy of Marketing Science, 16(1), 76-94. https://doi.org/10.1007/BF02723327

Baughman, L. (2010). Friend request or foe? confirming the misuse of Internet and social networking sites by domestic violence perpetrators, Widener Law Journal, 19(3), 933-966.

Blossom, J. (2009). Content Nation. surviving and thriving as social media changes our work, our lives, and our future, http://www.contentnation.com.

Cemrek, F., Baykuş, H., Özaydın, Ö. (2014). The analysis of social media use and behaviors within the scope of use and saturation approach: The case of Eskişehir Osmangazi University), Alphanumeric Journal, 2(2), 61-76.

Dikener, O. (2010). Web design in the Internet advertisement. Konya: Aybil Publishing.

Donelan, H. (2016). Social media for professional development and networking opportunities in academia, Journal of Further and Higher Education, 5(40), 706-729. https://doi.org/10.1080/0309877X.2015.1014321

Ebizmba, (2014). Top 15 Most Popular Social Networking Sites, http://www.ebizmba.com/articles/social-networking-websites.

Fouts, J. (2009). Social media success! Practical advice and real world examples for social media engagement. California: Happy About.info.

Haciefendioğlu, Ş. (2010). A study on membership commitment in social media sites, Kocaeli University Journal of Social Sciences Institute, 20(2), 56-71. 
Ilgar Araç, E., Cihan, B. B. (2018). Purposes and Characteristics of Internet Use Among Students Studying at School of Physical Education and Sports. Çetin, T., Şahin A., Mulalıc A., Obralıc, N. New horizones in education sciences II (175-194). Riga: Lambert Academic Publication Press.

Jang, K. Park, N. Song, H. (2016). Social comparison on facebook: its antecedents and psychological outcomes, Computers in Human Behavior, 62, 147-154. https://doi.org/10.1016/j.chb.2016.03.082

Kahraman, M. (2010). Social Media, Introduction to Social Media for Marketing. İstanbul: Mediacat Publications.

Karakoç, E., Taydaş, O. (2013). The relationship between university students' use of Internet as a free time activity and loneliness: The case of Cumhuriyet University, Selçuk Journal of Communication, 7(4), 33-45.

Kilci, A.K. (2018). The Impact and Role of Social Media Use on Watching Sports Channels, MA Thesis, University of Balıkesir, Institute of Health Sciences, Balıkesir.

Kural, S. Türkmen, M. Dilek, A.N. (2016). The analysis of the relationship between students' habits of social media use and their characters at School of Physical Education and Sports at University of Bartin, International Journal of Science Culture and Sport, 4(3), 870-881. https://doi.org/10.14486/IntJSCS637

Küçükali, A. (2016). University students' social media use: The case of Ataturk University, University of Bartın, Journal of Economic and Administrative Sciences, 7(13), 538-543.

Nunnally, J.C., Bernstein, I.H. (1994). Psychometric Theory, McGraw Hill: New York.

Otrar, M., Argin, F.S. (2014). The analysis of students' attitudes towards social media within the framework of using habits, Journal of Educational Research, 3(3), 1-13.

Önür, N., Kalaman, S., Çoban, O. (2015). The Practices of Football Referees Traditional and Social Media Usage in the Process of Developing Their Professional Refereeing Knowledge, E-Journal of Intermedia, 2(2) $392-410$.

Sayımer, İ. (2008). Public relations in the virtual world. İstanbul: Beta Publishing.

Scott, D.M. (2010). The new rules of marketing and pr, John Wiley and Sons, New Jersey.

Solmaz, B., Tekin, G., Herzem, Z., Demir, M. (2013). An analysis on Internet and social media use, Selçuk University Academic Journal of Communication, 7(4), 23-32.

Şencan, H. (2005). Reliability and validity in social and behavioral measurements. Ankara: Seçkin Publishing.

Şimşek, O.F. (2007). Introduction to structural equation modelling, basic principles and lisrel application. Ankara: Ekinoks Publishing.

Toruk, İ. (2008). An Analysis of University Students' Social Media Using Habits, Selçuk University Journal of Social Sciences, 19, 475-479.

Viejo, A. Sanchez, D. (2016). Enforcing transparent access to private content in social networks by means of automatic sanitization, Expert Systems With Applications, 62, 148-160. https://doi.org/10.1016/j.eswa.2016.06.026

Vural, B., Bat, M. (2010). Social media as a new form of communication: A study on Ege University Faculty of Communication, Journal of Yaşar University, 20(5), 3348-3382.

Weinberg, T. (2009). The New Community Rules: Marketing On the Social Rules, O’Reilly Media, USA.

West, S. G., Finch, J. F., Curran, P. J. (1995). Structural Equation Models with Nonnormal Variables and Remedies. Cited by: Hoyle, R.H. (Ed.) (1995). Structural Equation Modeling: Concepts, Issues and Applications, Sage: London. 